\title{
Od fizycznej bariery do integratora miasta
}

\section{From a physical barrier to the city's integrator}

\section{Streszczenie}

Celem pracy jest redefinicja podstawowych pojęć teorii kompozycji urbanistycznej i opracowanie propozycji projektowej dla bariery funkcjonalno-kompozycyjnej, jaką stanowi rzeka. Wisła, będąca osią terenów zielonych, jest jedną z najbardziej charakterystycznych przestrzeni publicznych i nieodłącznym elementem miasta. Niestety, tereny te nadal pozostają obszarem zaniedbanym i nieatrakcyjnym dla mieszkańców miasta i turystów.

Słowa kluczowe: kompozycja urbanistyczna, Kraków, rewitalizacja, rzeka w mieście

\section{Abstract}

The aim of this study is to redefine the basic concepts of the urban composition theory and development of a design proposal for the Wisła river which is perceived as a functional and compositional barrier. Wisła, as the axis of the city's green areas, is one of the most distinctive public spaces and inseparable part of the city. Unfortunately, they are still neglected and unattractive for both locals and tourists.

Keywords: urban composition, Cracow, revitalisation, river in the city 
Niniejsza praca powstała w ramach warsztatów urbanistycznych pt. Bariery-granice-krawędzie, zorganizowanych w roku akademickim 2014/2015 w ramach studiów III stopnia na Wydziale Architektury Politechniki Krakowskiej. Celem zajęć była redefinicja podstawowych pojęć teorii kompozycji urbanistycznej, zawartych w tytule warsztatów, w oparciu o opracowanie propozycji projektowej dla jednej z trzech wybranych barier funkcjonalno-kompozycyjnych istniejących w przestrzeni miasta Krakowa.

W pracy skupiono się na omówieniu granicy geograficznej i bariery mentalnej, jaką stanowi rzeka. Wisła, będąca osią ogólnodostępnych terenów zielonych, jest jedną z najbardziej identyfikowalnych przestrzeni publicznych i nieodłącznym elementem kształtującym tożsamość miasta. Zielone tereny położone w bezpośrednim sąsiedztwie tkanki urbanistycznej, stanowią unikalne w skali europejskiej miejsce rekreacji i wypoczynku. Jak pokazują przykłady z całego świata, odpowiednie zagospodarowanie terenów nadrzecznych i stworzenie atrakcyjnej przestrzeni publicznej może w kluczowy sposób poprawić integrację miasta pod względem krajobrazowym, komunikacyjnym i kulturowym. Niestety, pomimo wielu pomysłów na zagospodarowanie ${ }^{1}$, bulwary nadal pozostają obszarem zaniedbanym i nieatrakcyjnym dla mieszkańców miasta i turystów. Dopiero we wrześniu 2013 roku pojawiły się pierwsze uregulowania planistyczne ${ }^{2}$. Brak inwestycji w tym obszarze skutkuje zaprzepaszczeniem możliwości tego zielonego obszaru, który mógłby stanowić wizytówkę miasta i stanowić element łączący jego poszczególne części. Rzeka w dalszym ciągu pozostaje krawędziq pomiędzy zróżnicowanymi dzielnicami miasta oraz trudno przekraczalną barierq, zarówno pod względem fizycznym, jak i w percepcji użytkowników.

Za podstawę opracowania przyjęto teorie Kazimierza Wejcherta i Kevina Lyncha, dotyczące postrzegania przestrzeni przez człowieka. To, w jaki sposób odbieramy otaczający nasz świat i jego elementy, bazuje na obrazie mentalnym, jaki tworzy się w naszej świadomości. Jest to proces subiektywny, bazujący na odbiorze miejsc, ich powiązań i czynności z nimi związanych. Mapa myśli jest zatem swoistą opinią na temat miejsca. Jak wykazał Kevin Lynch w badaniach z lat 50. XX wieku ${ }^{3}$, istnieje pięć głównych kategorii, które stanowią podstawę tego wirtualnego obrazu: drogi, rejony, węzły, punkty orientacyjne i granice. W celu stworzenia przestrzeni, która będzie atrakcyjna dla użytkownika, należy zapewnić wystarczającą ilość tych składowych i sprawić, aby były one czytelne i łatwe do przyswojenia. Dzięki temu mentalna mapa szybko powstanie w świadomości odbiorcy, stanie się dla niego znajoma i zwiększy jego poczucie bezpieczeństwa.

Proponowane rozwiązania planistyczne, których głównym celem jest podkreślenie metropolitalnego znaczenia bulwarów, bazują na zwiększeniu dostępności komunikacyjnej, aktywizacji rozwoju kulturalnego oraz stworzeniu atrakcyjnej przestrzeni rekreacyjnej. Wykorzystanie istniejących możliwości krajobrazowych, wraz z położeniem szczególnego nacisku na zachowanie niezwykle cennej panoramy miasta i dziedzictwa kulturowego, może przyczynić się do stworzenia nadzwyczajnej przestrzeni publicznej, będącej integratorem miasta. Należy podkreślić, że przedstawione propozycje nie są szczegółowym rozwiązaniem projektowym, ale ideową koncepcją, która ma na celu pobudzenie dyskusji na temat funkcji 
rzeki we współczesnym mieście. Stworzenie poprawnego merytorycznie projektu dla tego obszaru wymagałoby pracy interdyscyplinarnego zespołu, który miałby możliwość przeprowadzenia analiz za zakresu wielu dziedzin (administracja, ochrona środowiska, socjologia, transport, urbanistyka itd.). Dopiero przy takich podstawach można pokusić się o stworzenie projektu zawierającego m.in. wytyczne dla systemu zieleni i nowej zabudowy. Z uwagi na skalę obszaru, jaki zajmują Bulwary Wiślane w przestrzeni miasta, niniejsza praca ogranicza się do analizy terenu na odcinku od mostu Zwierzynieckiego do mostu Dębnickiego i propozycji funkcjonalnego połączenia ze sobą Dębników i Zwierzyńca.

Wieś Dębniki została przyłączona do miasta w 1909 roku jako XI dzielnica katastralna. Obecnie ten jeden z największych obszarów administracyjnych miasta funkcjonuje jako Dzielnica VIII, obejmująca Bodzów, Kostrze, Pychowice, Skotniki, Zakrzówek oraz osiedla: Podwawelskie i Ruczaj. Zakres koncepcji został zawężony do obszaru ograniczonego osią Wisły od północy oraz ulicami Generała Bohdana Zielińskiego i Monte Cassino od południa. Przeważającą tkanką urbanistyczną tego terenu jest wolno stojąca zabudowa mieszkalna jedno- i wielorodzinna. Od strony wschodniej znajduje się jeden węzeł w postaci rynku Dębnickiego, wokół którego zabudowa jest zintensyfikowana w postaci trzy- i czterokondygnacyjnych kamienic miejskich. W tym miejscu znajduje się przeważająca część usług, których ilość jest niewielka w pozostałej części obszaru. Za tereny o wysokich walorach przyrodniczych uznano ${ }^{4}$ blisko pięciohektarowy park miejski, rozciągający się od ulicy Praskiej do neorenesansowego pałacu Lasockich, a także bulwar nadrzeczny na odcinku od wspomnianego pałacu do mostu Dębnickiego. Niestety, bulwary są obecnie zaniedbane: brakuje trasy spacerowej, położonej bezpośrednio nad lustrem wody, elementów małej architektury, oświetlenia ścieżek pieszo-rowerowych, nie wspominając o innej infrastrukturze.

Zwierzyniec to jeden z najstarszych ośrodków osadniczych w regionie. Prace archeologiczne ujawniły ślady stałej osady datowanej na okres paleolitu 5 . Na obszar Dzielnicy VII Zwierzyniec składa się kilka historycznych miejscowości: Błonia, Las Wolski, Olszanica, Półwsie Zwierzynieckie, Przegorzały, Wola Justowska, Zwierzyniec, które na przestrzeni lat były sukcesywnie przyłączane do miasta Krakowa. Obszar objęty projektem został ograniczony do terenu bezpośrednio sąsiadującego z centrum miasta, mieszczącego się między alejami Zygmunta Krasińskiego, Marszałka Ferdynanda Focha, ulicą Jacka Malczewskiego oraz rzeką Wisłą. Główny typ zabudowy to kamienice śródmiejskie: obiekty mieszkaniowe wielorodzinne z usługami zlokalizowanymi w parterze. Trudno wyróżnić jakiekolwiek punkty, które zgodnie z definicją Lyncha stanowiłyby węzły. Dwa miejsca - plac Na Stawach i pętla tramwajowa przy skrzyżowaniu ul. Królowej Jadwigi i ul. Tadeusza Kościuszki - noszą znamiona punktu krystalizującego przestrzeń. Wyróżniono ${ }^{6}$ natomiast jeden obszar o najwyższych walorach przyrodniczych, czyli teren zakonu sióstr norbertanek, znajdujący się przy ujściu rzeki Rudawy do Wisły. Obszar nadrzeczny jest częściowo zagospodarowany. Na umocnionym brzegu rzeki poprowadzony jest chodnik i ścieżka rowerowa, jednak tylko na odcinku od mostu Dębnickiego do rzeki Rudawy. 
Dzielnice różnią się pod względem funkcjonalnym i formalnym. Zwierzyniec posiada zaplecze usługowe, którego szczególnie brakuje po drugiej stronie rzeki. Z kolei zielone Dębniki są miejscem rekreacji na świeżym powietrzu i oferują tereny do wypoczynku od miejskiego zgiełku. Z tych powodów skupiono się na opracowaniu łącznika, który spowoduje wzajemne uzupełnienie tych funkcji. W opinii Kazimierza Wejcherta ${ }^{7}$ granice mogą stanowić jedyne w swoim rodzaju miejsce, które w sposób reprezentatywny pokazuje charakter danego rejonu. Z uwagi na swoją szerokość pasmo Bulwarów Wiślanych pozwala na uzyskanie panoramicznego widoku na obydwa obszary. $Z$ tego powodu przyjęto założenie o podkreśleniu istniejących różnic formalnych i uwypuklenie charakteru dzielnic, co pozytywnie wpłynie na dywersyfikację poszczególnych rejonów miasta i wzmocnienie patriotyzmu lokalnego.

Prace nad koncepcją zostały poprzedzone analizami obszaru pod kątem kategorii opracowanych przez Lyncha. Wyróżniono kilka podstawowych problemów, których rozwiązanie pozwoli na stworzenie atrakcyjnej przestrzeni łączącej dwie dzielnice miasta. Pierwszym rozpatrywanym elementem są drogi i związana z nimi komunikacja. Zgodnie z definicją droga stanowi łącznik między określonymi punktami. Nawet pobieżne spojrzenie na obecny stan infrastruktury obszaru bulwarów pozwala zauważyć brak ciągłości tras pieszych i rowerowych. Bulwar Rodła na lewym brzegu Wisły niespodziewanie urywa się w okolicach klasztoru sióstr norbertanek, wymagając od użytkowników cofnięcia się do ulicy Tadeusza Kościuszki w celu przeprawy przez Rudawę. Dalsza droga, wiodąca przy ulicy Księcia Józefa, jest odseparowana od Wisły wysokim murem. Po tej stronie rzeki znajduje się też ścieżka rowerowa, położona nad Rudawą i prowadząca do Balic, która na odcinku od ul. Salwatorskiej do al. Marszałka Ferdynanda Focha jest nieutwardzona i pozbawiona innej infrastruktury. Z kolei na całej długości prawobrzeżnego bulwaru brakuje ścieżki położonej bezpośrednio nad lustrem wody. Z uwagi na brak oświetlenia bulwary wykorzystywane są obecnie tylko w ciągu dnia. Kolejnym problemem jest stan mostów. Brakuje najprostszej infrastruktury, takiej jak schody i rampy, które bezpośrednio łączyłyby poziom mostu z bulwarem. To wpływa na wydłużenie drogi, którą trzeba pokonać, aby przedostać się na drugi brzeg. Dodatkowo intensywny ruch kołowy sprawia, że mosty są odbierane jako niebezpieczne, a prawie dwukilometrowa odległość między nimi skutecznie zniechęca użytkowników do spaceru.

W odpowiedzi na zauważone problemy opracowano następujące rozwiązania, zwracając wyjątkową troskę o zachowanie osi widokowych na najważniejsze elementy panoramy miasta: Wzgórze Wawelskie, sylwetę Starego Miasta i klasztor sióstr norbertanek. Uzupełniono wspomniane wcześniej odcinki tras pieszych, dodając także oświetlenie i elementy małej architektury. Na odcinku od klasztoru norbertanek do mostu Zwierzynieckiego zaproponowano stworzenie podniesionej promenady, znajdującej się na poziomie ulicy Tadeusza Kościuszki, pod którą przewidziano przestrzeń użytkową przeznaczoną na potrzeby policji wodnej, WOPR-u i klubu kajakowego. W celu uatrakcyjnienia istniejących przepraw przewidziano dodatkowe kładki pieszo-rowerowe przy istniejących mostach, odseparowane od ruchu kołowego. 
Kluczowym elementem koncepcji jest projekt nowej kładki dla pieszych i rowerzystów, która będzie kulminacyjnym punktem połączenia między dzielnicami. Jej lokalizacja została opracowana na podstawie czterech kryteriów: stopnia powiązania z traktami pieszych, odległością do istniejących mostów, stworzenia nowego punktu widokowego oraz zachowania widoku na Wzgórze Wawelskie i klasztor norbertanek. Obszar objęty koncepcją stanowi przedpole dla sylwety Starego Miasta oraz jest objęty strefą ochrony i kształtowania krajobrazu, dlatego ostatnie z podanych kryteriów było elementem o największym znaczeniu. Za najbardziej dogodne uznano miejsce znajdujące się na wysokości parku Dębnickiego i klasztoru norbertanek. Dzięki takiej lokalizacji nie tylko nie zakłócono istniejących osi widokowych, ale także otrzymano nowy panoramiczny punkt widokowy, który może stanowić atrakcję turystyczną. Co więcej, takie umiejscowienie pozwala również na połączenie pasa zieleni rekreacyjnej, ciągnącego się z północy na południe (od kopca Kościuszki i rzekę Rudawę do Skał Twardowskiego przez park Dębnicki). Koncepcja nie precyzuje jednak formy architektonicznej kładki, która powinna zostać opracowana z dbałością o szczegóły w trosce o zachowanie charakteru miejsca.

W kwestii komunikacji publicznej proponowane jest uzupełnienie sieci tramwajowej przez przedłużenie trasy z pętli na Salwatorze, przez most Zwierzyniecki do linii przy ul. Monte Cassino. Pozwoli to na zmniejszenie ruchu kołowego. Sugerowana jest też wymiana taboru kolejowego i torowisk w celu ograniczenia ilości hałasu. Wisła to nie tylko przestrzeń krajobrazowa i rekreacyjna, a rzekę należy rozpatrywać również jako drogę wodną. Istniejący tramwaj wodny jest traktowany w tej chwili jako atrakcja turystyczna, a nie transport miejski. Ma na to wpływ nieregularny rozkład jazdy, wysoki koszt biletów i długi czas podróży. Dodatkowo przystanki zlokalizowane są w bardzo dużych odległościach od siebie, co jest bardzo widoczne pomiędzy Salwatorem i Kolejowym Klubem Wodnym 1929 oraz mostem Dębnickim i Kazimierzem. Założono uzupełnienie sieci o cztery nowe przystanki: na prawym brzegu przy moście Zwierzynieckim i parku Dębnickim, a na lewym przy skrzyżowaniu ul. Białe Wzgórze z ul. Księcia Józefa oraz przy zakolu Wisły pod Wawelem. Pozwoli to na stworzenie nowych tras, zarówno turystycznych (wolnych, obsługiwanych jednostkami zabytkowymi), jak i miejskich (szybkich, opartych o nowoczesny tabor rzeczny). Dzięki temu komunikacja drogą wodną zostanie zintensyfikowana, odciążając komunikację kołową. Ważnym aspektem jest stworzenie atrakcyjnych przystanków w postaci nowej kubatury, pozwalającej na zmieszczenie funkcji towarzyszących, takich jak mała gastronomia, punkty informacji turystycznej, toalety czy pomieszczenia dla służb porządkowych.

Zdaniem Kazimierza Wejcherta ${ }^{8}$ obszary graniczne pozwalają na spojrzenie na rejony w ich pełnej okazałości. Niestety, obecny stan zabudowy po obu stronach rzeki pozostawia wiele do życzenia. Wyjątkowo mało atrakcyjna jest tkanka urbanistyczno-architektoniczna na lewym brzegu Wisły: budynki sąsiadujące z bulwarem to przede wszystkim obiekty zaplecza, odcięte od rzeki wysokim murem. Brakuje przestrzeni publicznych otwartych na ciąg pieszy bulwarów i funkcji, które przyciągnęłyby użytkowników. Na terenie Dębników przeważa natomiast wolno stojąca zabudowa jedno- i wielorodzinna pełniąca funkcje mieszkaniowe. 
W koncepcji założono podkreślenie specyficznego charakteru dzielnic, ich zespołów urbanistycznych i formy architektonicznej. Z uwagi na istniejącą strukturę urbanistyczną na obszarze lewego brzegu rzeki podjęto decyzję o uzupełnieniu śródmiejskiej zabudowy, zachowując charakter i gabaryty istniejącej architektury. Wyjątkowo ważne jest stworzenie nowych przestrzeni publicznych z usługami komercyjnymi zlokalizowanymi w parterze i otwartymi na ciąg bulwarów nadrzecznych. W połączeniu z podniesionym bulwarem stworzy to pierwszy fragment nabrzeża miejskiego, który stanie się wizytówką miasta Krakowa od strony rzeki. Przewidziano także miejsce na infrastrukturę związaną z żeglugą, czyli pomosty i urządzenia do cumowania, które pozwolą na ożywienie turystyki i rekreacji. Na obszarze Dębników zaproponowano natomiast uwypuklenie wartości przyrodniczych i krajobrazowych. Utrzymanie istniejących parków miejskich, skwerów i alei wymaga opracowania planu jasno określającego granice obszarów przeznaczonych do zabudowy i zapobiegającego chaotycznej rozbudowie.

Następnym rozpatrywanym elementem są węzły oraz ich wzajemne połączenia. Brak punktów krystalizujących przestrzeń urbanistyczną negatywnie wpływa na odbiór miasta i tworzenie mapy poznawczej. Na obszarze objętym projektem tylko rynek Dębnicki spełnia kryteria takiego punku. Wyróżniono natomiast dwie inne lokalizacje, które można przekształcić w węzły: plac Na Stawach i pętla tramwajowa przy ul. Tadeusza Kościuszki. Założono połączenie tych trzech punktów przez wiele otwartych przestrzeni publicznych, ujednoliconych formalnie przez rysunek posadzki, zagospodarowanie zieleni i elementy małej architektury. Ograniczono też ruch kołowy na tym obszarze, jednocześnie zapewniając dostęp do sieci komunikacji miejskiej. Ostatecznie zaproponowano obiekty, które mogą stanowić lokalne dominanty: kościół św. Augustyna i św. Jana Chrzciciela przy nowej kładce pieszo-rowerowej, pałac Lasockich w parku Dębnickim oraz Dworek Łowczego z przedpolem w postaci ulicy Jaskółczej i terenów klubu sportowego AZS-AWF, przekształconych w plac o charakterze miejskim.

Chociaż dolina Wisły na terenie miasta Krakowa to obszar silnie przekształcony przez człowieka, bulwary stanowią ważny element środowiska przyrodniczego. Na przestrzeni wieków dokonano zmiany naturalnego biegu rzeki, wybudowano stopnie wodne (tzw. Kaskada Górnej Wisły) i osuszono okoliczne bagna. Pomimo wielu zmian środowiska naturalnego obszar Bulwarów Wiślanych został w całości uznany za cenny przyrodniczo ${ }^{9}$. Jest on ważnym elementem dla poprawy warunków klimatycznych miasta ${ }^{10}$, ponieważ stanowi jego korytarz przewietrzający. Przede wszystkim wartościowy jest prawy brzeg rzeki, który z uwagi na niewielki poziom zurbanizowania pozostaje w równowadze przyrodniczej. Tutaj, w oparciu o istniejące tereny zielone, zaproponowano ogólnodostępne przestrzenie publiczne, takie jak parki spacerowe, ścieżki rowerowe, sportowe urządzenia terenowe. Ciekawą możliwością jest też stworzenie parku dydaktycznego i otwartego muzeum rzeźby na otwartym powietrzu. Należy mieć na uwadze, że bardziej intensywna ingerencja mogą naruszyć istniejącą równowagę ekologiczną. 
Granice dzielące poszczególne obszary miejskie nie muszą stanowić fizycznych i mentalnych barier. Nowe atrakcyjne przestrzenie publiczne na obszarze Bulwarów Wiślanych pozwolą na rozwój kulturalny i zapewnią miejsce do wypoczynku na świeżym powietrzu, co stanowi bardzo atrakcyjną szanse dla rozwoju miasta. Zmiany proponowane w niniejszym projekcie wpływają na polepszenie warunków życia mieszkańców. Rewaloryzacja terenów nadwiślańskich pozwala nie tylko na stworzenie wizytówki miasta od strony rzeki, ale umożliwi integrację poszczególnych dzielnic pod względem krajobrazowym, komunikacyjnym i kulturowym. Dzięki temu istniejąca obecnie bariera stanie się elementem scalającym miasto. 

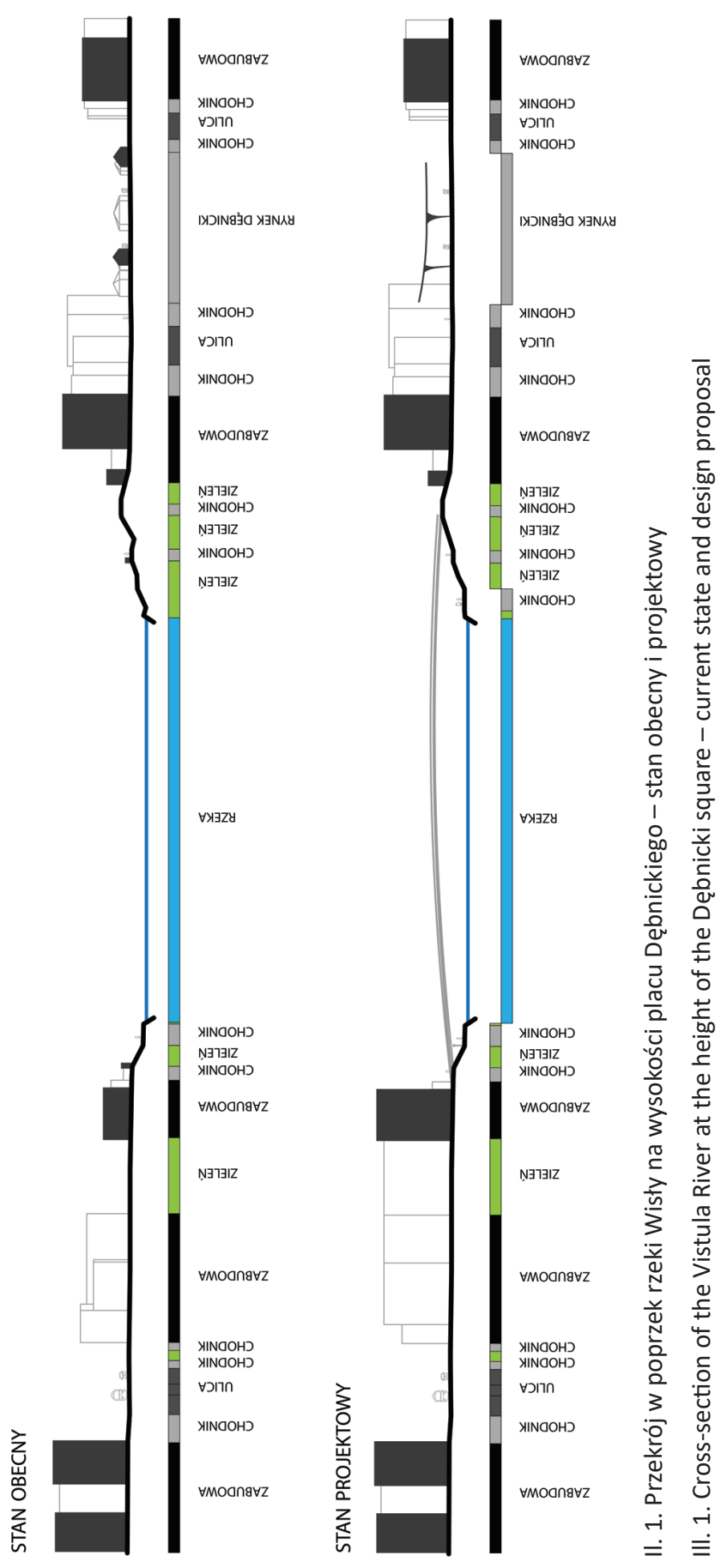


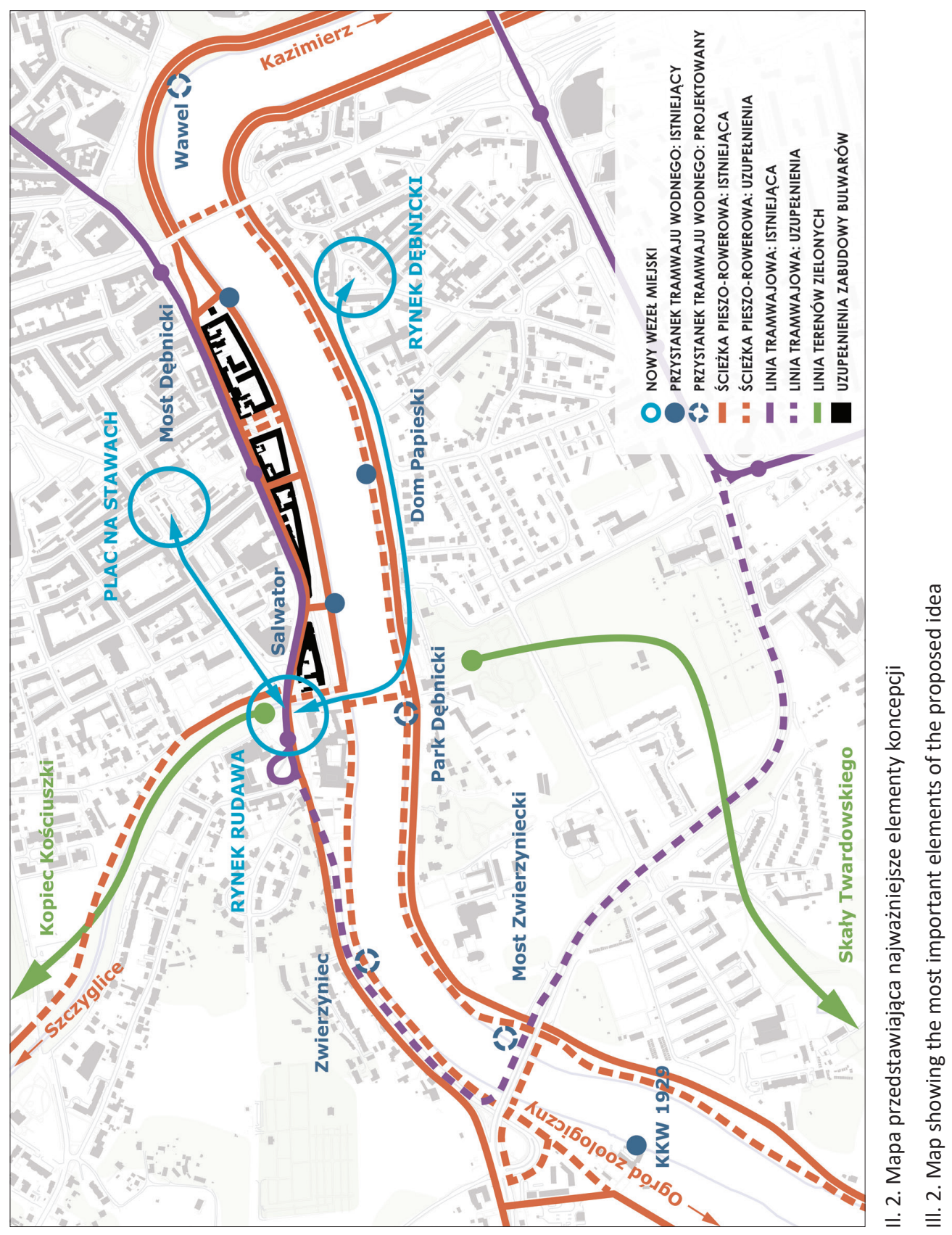




\section{PRZYPISY}

1 M.in.: konkurs na opracowanie koncepcji Zagospodarowania przestrzennego Doliny Wisły w Krakowie na odcinku od Mostu Zwierzynieckiego po stopień wodny na Dąbiu, organizowany przez Gminę Miejską Kraków (2008), konkursy Kraków frontem do Wisły i Architektura bulwarów w ramach VII Międzynarodowych Biennali Architektury w Krakowie (1998).

2 Uchwała nr LXXXI/1240/13 Rady Miasta Krakowa z dnia 11 września 2013 r. w sprawie uchwalenia miejscowego planu zagospodarowania przestrzennego obszaru „Bulwary Wisły”.

3 K. Lynch, Obraz miasta, Archivolta, Kraków 2011.

4 Urząd Miasta Krakowa, Wydział Kształtowania Środowiska, Mapa roślinności rzeczywistej Miasta Krakowa "Zielony Kraków", http://zielony-krakow.um.krakow.pl/ (dostęp: 15.01.2015).

5 W. Chmielewski, Badania stanowiska paleolitycznego Kraków-Zwierzyniec I w latach 19721974, „Sprawozdania Archeologiczne”, nr 28, 1976, s. 19-27.

6 Urząd Miasta Krakowa, Mapa roślinności..., op. cit.

7 K. Wejchert, Elementy kompozycji urbanistycznej, Arkady, Warszawa 2008.

8 Ibidem.

9 Urząd Miasta Krakowa, Biuro Planowania Przestrzennego Pracownia Branżowa: Miejscowy plan zagospodarowania przestrzennego obszaru „Bulwary Wisły”: Prognoza oddziaływania na środowisko, Kraków 2013, s. 11.

10 Wojewódzki Inspektorat Ochrony Środowiska w Krakowie, Wydział Monitoringu Środowiska, Ocena jakości powietrza w województwie małopolskim w 2009 roku, Kraków 2008.

\section{BIBLIOGRAFIA}

Chmielewski W., Badania stanowiska paleolitycznego Kraków-Zwierzyniec I w latach 19721974, „Sprawozdania Archeologiczne”, nr 28, 1976, s. 19-27.

Lynch K., Obraz miasta, Archivolta, Kraków 2011.

Lynch K., Growing Up in Cities, MIT Press, Cambridge 1977.

Wejchert K., Elementy kompozycji urbanistycznej, Arkady, Warszawa 2008.

Uchwała nr LXXXI/1240/13 Rady Miasta Krakowa z dnia 11 września 2013 r. w sprawie uchwalenia miejscowego planu zagospodarowania przestrzennego obszaru „Bulwary Wisły”.

Urząd Miasta Krakowa, Biuro Planowania Przestrzennego Pracownia Branżowa, Miejscowy plan zagospodarowania przestrzennego obszaru „Bulwary Wisły”: Prognoza oddziaływania na środowisko, Kraków 2013.

Urząd Miasta Krakowa, Wydział Kształtowania Środowiska, Mapa roślinności rzeczywistej Miasta Krakowa „Zielony Kraków”, http://zielony-krakow.um.krakow.pl/ (dostęp: 15.01.2015).

Wojewódzki Inspektorat Ochrony Środowiska w Krakowie, Wydział Monitoringu Środowiska, Ocena jakości powietrza w województwie małopolskim w 2009 roku, Kraków 2008. 